\title{
An unusual cause of systemic calcification-Fibrodysplasia Ossificans Progressiva
}

\author{
Sourya Sourabh Mohakuda ${ }^{1}$, Rajneesh Thakur ${ }^{1}$ and Abdul \\ Saleem ${ }^{2 *}$ \\ ${ }^{1}$ Clinical Tutor, Department of Internal Medicine, AFMC, Pune, India \\ ${ }^{2}$ Resident, Department of Internal Medicine, AFMC, Pune, India
}

Received: 30 December, 2019

Accepted: 22 February, 2020

Published: 24 February, 2020

*Corresponding author: Abdul Saleem, Resident, Department of Internal Medicine, AFMC, Pune, India, E-mail: drabdulsaleem@gmail.com

Keywords: Fibrodysplasia ossificans progressiva; Myositis ossificans; Heterotopic ossification

https://www.peertechz.com

Check for updates

\section{Abstract \\ Fibrodysplasia Ossificans Progressiva is a rare (incidence-one in two million people ${ }^{3}$ ) and disabling genetic condition, diagnosis of which is generally based on presence of congenital abnormality of great toes, progressive heterotopic ossification and the classical pattern of disease progression and radiological findings. Our case, a 29year old male presented with deformity of bilateral great toes since childhood, multiple hard swellings all over body leading to painful restriction of joint mobility and limitation of routine activities. Radiograph and bone scan revealed multiple sites of heterotopic ossifications.}

\section{Introduction}

Fibrodysplasia ossificans progressiva is a rare disabling genetic disorder and is also known as myositis ossificans progressiva or Munchmeyer disease or Stone man disease [1]. It is characterised by congenital malformation of great toes and progressive heterotopic enchondral ossification. There is proliferation of connective tissue, with progressive ectopic and episodic ossification of soft tissues such as fascia, muscles, tendons and ligaments. Patients present with painful swellings, and after subsidence of swellings, ossification and heterotopic bone formation occurs at the same sites. Eventually this new bone formation interferes with normal movements of patient leading to immobilization.

\section{Case report}

A 29year old male presented with deformity of bilateral great toes since childhood, multiple hard swellings all over body-initially in thigh, progressed to involve right knee, left shoulder, right elbow right shoulder and neck from 06years of age. He had painful restricted movements of joints which lead to difficulty in walking, squatting and raising arm above, with no features suggestive of neurological weakness. He had full term normal vaginal delivery with no developmental delay. There was no history of similar illness in family. On examination he was noticed to have deformity of bilateral toes, hard swelling over paraspinal (upper thoracic), periscapular regions, right arm, right knee, right thigh, left leg, chest wall and upper back; and stiffness over neck, right elbow, left shoulder and right wrist. There was no associated skin changes.

Investigations revealed-Hb-13.2g/dl, TLC-7600/cumm (P58 L32 M 6), Plt-2.3L/cumm; Blood Urea/S. Cr26/o.8mg/dl, S.Na/K-136/4.2meq/L, Calcium/Po4-9.8/2.8mg/dl, S.Bilirubin$0.6 \mathrm{mg} / \mathrm{dl}, \mathrm{T}$ Protein/Alb-8.1/4.6g/dl, AST/ALT-24/26IU/L, ALP-95IU/L, CPK-90IU/L, 24hour urinary calcium-204mg/ day, iPTH-194.7 pg/ml, Spirometry-restrictive pattern. Radiograph AP view of thigh, leg and arms showed multifocal heterotopic ossification. Skeletal survey revealed no lytic lesions. Bone scan showed multiple sites of heterotopic ossification. To confirm the diagnosis, bone biopsy was done from right thigh which revealed cortical bone and mature bony trabeculae with marrow spaces. There was no cartilage or atypical cells seen. The biopsy was consistent with heterotopic ossification (Figures 1-4).

\section{Discussion}

Fibrodysplasia ossifificans progressiva, is a rare genetic disease. Its incidence is one in two million population $[2,3]$, with no racial, sex or geographic predisposition. Literature 
review reveals only around 600 reported cases world wide [4]. It usually occurs sporadically and also can be inherited as autosomal dominant condition with wide range of expression [5]. It affects connective tissues and there has been reported heterozygous mutation in activin receptor IA/activin-like kinase 2 (ACVR1/ALK2) [3], a bone morphogenetic protein (BMP) type I receptor, in sporadic as well as familial cases of classic disease. The distinguishing features are heterotopic ossifictions and abnormalities of digits of hands and feet. Individual usually appears normal at birth and the abnormal ossification starts by the mean age of 5years [5,6] which is episodic and progressive. The affected child is usually noticed to have abnormal great toes which may be short, monophalangic and with valgus deformity as it was in our case $[7,8]$. Abnormalities of the great toes are usually present in 79-

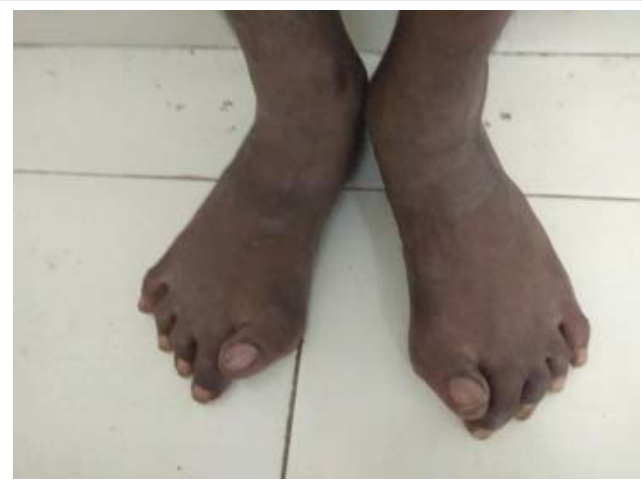

Figure 1: Charecteristic great toe deformity in fibrodysplasia ossificans progressive as seen in our patient

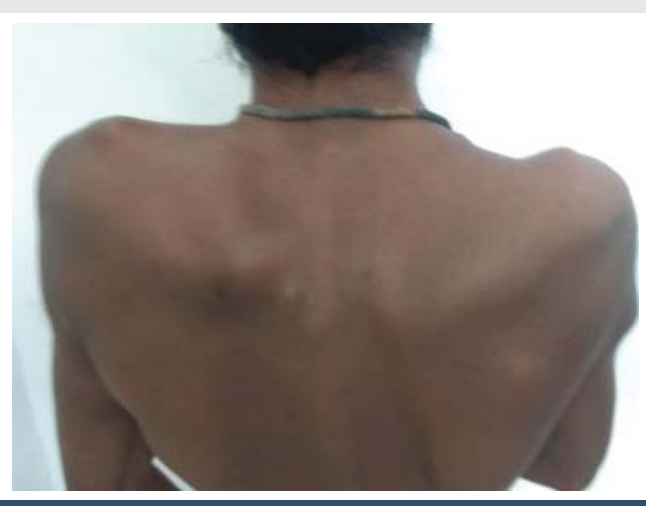

Figure 2: Multiple paraspinal swellings seen in our patient.

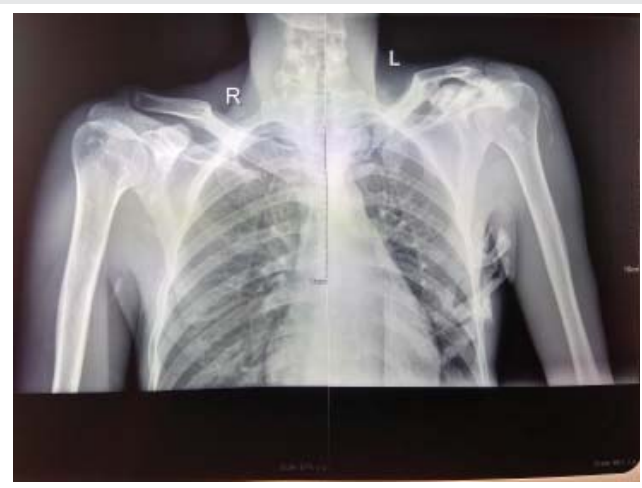

Figure 3: Heterotopic ossification seen on Chest X Ray film-PA view.

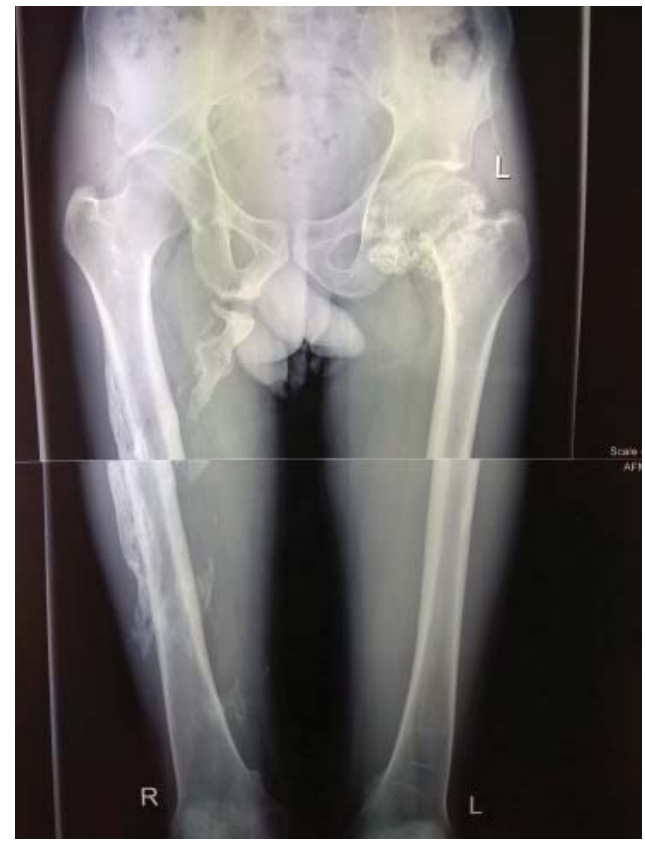

Figure 4: Heterotopic ossification seen in bilateral femur on X Ray film.

$100 \%$ of patients [8]. Other skeletal deformities like short first metacarpal, clinodactyly of the fifth finger and broad femoral necks can be present. Most cases of abnormal ossification starts at neck which progresses downwards from axial to appendicular skeleton. Along with these, there can be deafness in about one fouth cases and mental retardation though can be present is very rare $[9,10]$. Our case had a normal audiometry reading and needs to be followed up for hearing loss in future.

Initially there is head and neck involvement with soft tissue swellings or nodules with torticollis. These swellings are often painful. The swellings and ossification then appears in other parts of body, which occurs more commonly spontaneously and may flare-up after trauma [11]. The involvement is episodic but progressive, usually with a typical pattern. There is predilection for scalp, paraspinal, jaw muscles with a proximal to distal gradient of muscles of arms and legs [11]. Facial muscles, tongue, diaphragm are often spared with only rare involvement of abdominal muscles [11]. Ultimately there is restricted movement and deformities depending on the area and extent of involvement. The common cause of death in these patients is respiratory compromise which occurs due to involvement of thoracic cage muscles, joints along with spinal deformity leading to decreased intrathoracic volume and lung functions. Usually these patients become dependent and confined to wheel chair or bed by second to third decade.

Diagnostic errors are common in cases of FOP amounting upto $87 \%$ worldwide, and cancer being most frequent incorrect diagnosis [12]. The usual differential diagnoses in early stage of disease with focal ossified masses are tumoral calcinosis, some bone malignancies (juxtacortical osteosarcoma), soft tissue sarcoma,nodular fascitis and fibromatoses [5]. FOP is basically a clinico-radiological diagnosis. After clinical suspicion plain conventional radiography can provide more knowledge about deformities of great toes, hands and other skeletal structures, 
and the ectopic ossifications. Hematological and Biochemical tests including renal and liver function tests, serum alkaline phosphatases, serum and urinary calcium and phosphate levels and parathyroid hormone levels are usually within the normal range. Bone scintigraphy with $99 \mathrm{mTc}-$ methyl-diphosphonate shows abnormal uptake in preosseous soft tissue and is useful in establishing cases with early Heterotopic Ossification [9]. Abnormal ossifications can be precipitated by iatrogenic trauma. Thus, biopsy and surgical procedures are often avoided. In our case we did a bone biopsy to rule out any atypical cells as it would have given an option of definitive cure to the patient.

Medical intervention is mainly supportive. Glucocorticoids, NSAIDs, COX-2 inhibitors, leucotriene inhibitors and mast cell stabilizers are useful in managing the long term discomfort and intermittent flare-ups [2]. Chronic immunosuppression may have some benefit [2]. Surgical release of joint contractures and other surgical procedures are generally unsuccessful. Till date no effective therapy has been described in altering natural history of disease [3]. As it is a heritable disorder (autosomaldominant or spontaneous mutation), genetic counseling may play a role in the prevention of disease. Our patient is presently on NSAIDs and is on follow up for last 6months. Care is being taken to give supportive care to minimise his dependency in activities of daily living.

\section{References}

1. Schober P, Krage R, Thone D, Loer Stephan A, Schwarte Lothar A (2009) Ultrasound-guided ankle block in stone man disease, fibrodysplasiaossificans progressiva. Anesth Analg 109: 988-990. Link: http://bit.ly/32mqlbM

2. Pignolo RJ, Shore EM, Kaplan FS (2013) Fibrodysplasia Ossificans Progressiva: Diagnosis, management, and therapeutic horizons. Pediatr Endocrinol Rev 10 437-448. Link: http://bit.ly/2T9fd3x
3. Kaplan FS, Merrer ML, Glaser DL (2008) Fibrodysplasia Ossificans Progressiva. Best Pract Res Clin Rheumatol 22: 191-205. Link: http://bit.ly/32njjsW

4. Majmudar DK, Hathila NN, Vaishya KB, Sayani, Trivedi AV, et al. (2005) Fibrodysplasia Ossificans Progressive. Indian J Radiol Imaging 15: 347-348. Link: http://bit.ly/37Ug7pQ

5. Magryta CJ, Kligora CJ, Temple H (1999) Clinical presentation of Fibrodysplasia Ossificans Progressiva: pitfalls in diagnosis. J Pediatric Hematol Oncol 21: 539-543. Link: http://bit.ly/2HRLF4Y

6. Verma AK, Aga P, Singh SK (2012) The stone man disease: Fibrodysplasia Ossificans Progressiva: Imaging Revisited. Case Reports 2012: bcr2012006422. Link: http://bit.ly/39VbnBy

7. Rathee N, Gupta PK, Gupta K, Garg G (2016) Myositis Ossificans Progressiva: A clinico-radiological evaluation-Case report with brief review of literature. $J$ Orthop Allied Sci 4: 87-90. Link: http://bit.ly/2STg3T3

8. Smith R (1998) Fibrodysplasia (myositis) Ossificans Progressiva: Clinical lessons from a rare disease. Clin Orthop Rel Res 346: 7-14. Link: http://bit.ly/2wHUjRq

9. Trisha V, Kumar R, Khan SA, Shishir R (2005) Characteristic appearance on bone scintigraphy of a 'Stone Man'. Clin Nucl Med 30: 517-518. Link: http://bit.ly/2HStdtg

10. Connor JM, Evans DA (1982) Fibrodysplasia Ossificans Progressiva, the clinical features and natural history of 34 patients. J Bone Joint Surg 64: 7683. Link: http://bit.ly/2utDEAm

11. Connor JM (1996) Fibrodysplasia Ossificans Progressiva-Lessons from Rare Maladies. N Engl J Med 335: 591-593. Link: http://bit.ly/3c4ITaE

12. Kitterman JA, Kantanie S, Rocke DM (2005) latrogenic harm caused by diagnostic errors in Fibrodysplasia Ossificans Progressiva. Pediatrics 116 654-661. Link: http://bit.ly/2vXy7SU

\section{Discover a bigger Impact and Visibility of your article publication with} Peertechz Publications

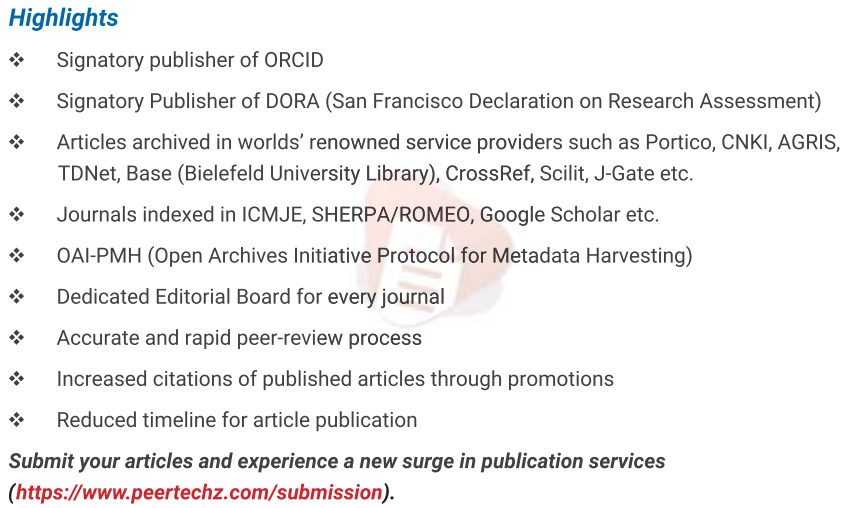

Peertechz journals wishes everlasting success in your every endeavours.

Copyright: @ 2020 Mohakuda SS, et al. This is an open-access article distributed under the terms of the Creative Commons Attribution License, which permits unrestricted use, distribution, and reproduction in any medium, provided the original author and source are credited.

Citation: Mohakuda SS, Thakur R, Saleem A (2020) An unusual cause of systemic calcification-Fibrodysplasia Ossificans Progressiva. Int J Clin Endocrinol Metab 6(1): 008-010. DOI: https://dx.doi.org/10.17352/ijcem.000044 